\title{
Preliminary studies on antimicrobial activities of ethanolic extracts of Ficus sycomorus Linn. and Ficus platyphylla Del. (Moraceae)
}

\author{
Gbonjubola Olusesan ADESHINA *, Claire-Lorentz EBERE OKEKE, Nonyelum \\ Osuagwu ONWUEGBUCHULAM and Joseph Olorunmola EHINMIDU
}

Department of Pharmaceutics and Pharmaceutical Microbiology, Faculty of Pharmaceutical Sciences, Ahmadu Bello University, Zaria, Nigeria.

*Corresponding author, E-mail: dotunkele@yahoo.com, Telephone No: 234-8037880000

\begin{abstract}
The phytochemical screening of the ethanolic extracts of leaf and stem bark of Ficus sycomorus and Ficus platyphylla was carried out using standard biochemical methods. The antimicrobial activities (i.e. zones of inhibition) of the ethanolic extracts of leaf and stem bark of Ficus sycomorus and Ficus platyphylla against Trichophyton mentagrophytes, ciprofloxacin-resistant Salmonella typhi and Staphylococcus aureus were investigated under varying temperature, $\mathrm{pH}$ and storage duration of nine months. The zones of inhibition of the test plants extracts were evaluated using agar diffusion methods. Phytochemical analysis revealed the presence of tannins, saponins, anthraquinone, glycoside, alkaloids, flavonoids, steroids and reducing sugars. The effects of temperature and $\mathrm{pH}$ on the antimicrobial activity of the extracts of the plants remained relatively unaffected at $\mathrm{P}>0.05$. There were no significant $(\mathrm{P}>0.05)$ changes in the antimicrobial activities of the extracts against the test organisms throughout the nine months period of investigation. The implications of these findings in the use of these plants are discussed.

(C) 2009 International Formulae Group. All rights reserved
\end{abstract}

Key words: Temperature, $\mathrm{pH}$, storage duration, chemical constituents

\section{INTRODUCTION}

Medicinal plants represent a rich source from which antimicrobial agents can be obtained (Kubmarawa et al., 2007). Nearly $70 \%$ of human population is reported to be dependent on plant-based medicines (Pravin, 2006).

Infections due to pathogenic bacteria and fungi represent a critical problem to human health and are one of the main causes of morbidity and mortality worldwide (Willey, 2008).

The Ficus species belong to the mulberry family, Moraceae which occurs primarily in tropical and semi-tropical regions, and includes a wide variety of herbs, shrubs, and trees, characterized by a milky sap and reduced, unisexual flowers. This family includes 40 genera and 1,000 species, of which 500 species are members of the fig genus, Ficus (Zerega et al, 2005). They are usually found near streams in the savannah area. Ficus sycomorus have been reported to possess antifungal (Hassan, 2006) and anti diarrhoea activities (Ahmadu et al., 2007). The sedative and anticonvulsant properties of this plant have also been reported (Sandabe et al., 2003). The extracts of Ficus platyphylla have been reported to inhibit gastro-intestinal motility (Amos et al., 2001). It has been reported to possess analgesic (Wakeel et al., 2004), anti-inflammatory and anticontraceptive (Amos et al., 2002) activities. Kubmarawa et al. (2007) reported the use of the stem bark in the treatment of tuberculosis. The extracts of these plants are used in Hausa 
ethno medicine of Northern Nigeria for the treatment of various ailments such as mental illness, dysentery, cough, diarrhoea, chest condition, tuberculosis, convulsive disorder and pain relief (Wakeel et al., 2004; Kubmarawa et al., 2009).

Various secondary metabolites which constitute an important source of the pharmaceutical drugs have been isolated from different parts of plants. Some of these compounds have been reported to be present in the Ficus species such as tannins, saponins, flavonoids, steroids, anthraquinone glycosides and reducing sugars (Hassan, 2005; Sandabe et al., 2006).

The capability of an active substance in a specific container/closure system to remain within its physical, chemical, microbiological and toxicological specification is referred to as stability of the substance (Webster, 2008). The antimicrobial activities of some plant metabolites have been reported to be unstable due to some factors. These factors which include enzymatic degradation, environmental conditions, air $\left(\mathrm{O}_{2}, \mathrm{CO}_{2}\right)$, light, heat, water (hydrolysis) and duration of time between storage and usage can lead to instability of the active substances (Oyi et al., 2007). Temperature, $\mathrm{pH}$ and the presence of water are the major factors that influence drug decomposition. Hydrolytic reaction and oxidative reactions are strongly influenced by environmental factors such as light, oxygen, metal ions and metals in trace quantities which trigger off these reactions (Aulton, 2000). Hydrolysis always occurs in active products containing an ester or amide linkage. The rate of hydrolysis depends on the quantity of water present, temperature and $\mathrm{pH}$ (Dumitinu, 2005). Increase in temperature increases the rate of chemical reactions in all active products (Webster, 2008). Deterioration of some thermolabile products usually occurs as a result of rapid rate of chemical reaction when normal range of temperature is exceeded (Aulton, 2000). Webster (2008) postulated that for every ten degree rise in temperature, the rate of chemical reactions doubles or triples.

The antimicrobial activities of plant extracts can be affected by the above mentioned factors, therefore this study was designed to document the phytochemical constituents of the test plants and their antimicrobial activities in relation to factors such as $\mathrm{pH}$, temperature and storage duration.

\section{MATERIALS AND METHODS \\ Collection and preparation of plants materials}

The leaves and stem bark of the two plants were collected in Samaru, Zaria, Nigeria, in July 2006. The plants were authenticated at the herbarium unit of the Department of Biological Sciences, Ahmadu Bello University, Zaria, Nigeria, where voucher specimens (1446) for Ficus sycomorus and (7230) for Ficus platyyphylla were deposited.

The air-dried powered plants parts (500mg each) were extracted with $70 \%$ aqueous ethanol at room temperature. The extracts were concentrated, dried and weighed (Brain and Tumer, 1975; Sofowora, 1993).

\section{Phytochemical analysis}

The extracts were subjected to phytochemical analysis to detect the presence of the chemical constituents using standard protocol (Trease and Evans, 1996; Sofowora, 1982).

Determination of effects of varying $\mathrm{pH}$ values on the antimicrobial activity of Ficus sycomorus leaf extract

Three different $\mathrm{pH}$ values $(\mathrm{pH} 4,7$, and 9) were employed. These were obtained and maintained using $\mathrm{pH}$ buffers. The various buffers were prepared according to the manufacturer's prescriptions and measured using $\mathrm{pH}$ meter. The extract $(2.5 \mathrm{~g})$ was added to $0.1 \mathrm{~g}$ of the buffer powder and the volume made up to $10 \mathrm{mls}$ with sterile distilled water. This gave a concentration of 250 $\mathrm{mg} / \mathrm{ml}$. The whole content was allowed to stand for 30 minutes.

The test bacteria and fungus were clinical isolates obtained from the Department of Pharmaceutics and Pharmaceutical Microbiology, Ahmadu Bello University, Zaria-Nigeria. Eighteen (18) hours bacteria broth cultures were standardized appropriately to about $10^{6} \mathrm{cfu} / \mathrm{ml}$. Similarly, the test fungi 
spores suspension were standardized according to Ehinmidu (2005) to $10^{6} \mathrm{sfu} / \mathrm{ml}$. Agar well diffusion method was carried out by flooding the sterile Mueller-Hinton agar (bacteria) and Sabouraud's dextrose agar (fungi) already poured and cooled in sterile petri-dishes with $2.0 \mathrm{ml}$ each of the standardized cultures $\left(10^{6} \mathrm{cfu} / \mathrm{ml}\right)$ of the test organisms. The plates were allowed to dry at room temperature. A sterile cork borer no. 4 ( $8 \mathrm{~mm}$ diameter) was used to bore hole in the agar plates. The bottom of the bored hole was sealed with one drop of molten sterile agar to prevent the extract from sipping beneath the agar. Using a micropipette, $0.1 \mathrm{ml}$ of the admixture was dispensed into the holes in duplicates. Sterile distilled water was also dispensed into one of the bored holes, which served as control. These were allowed to diffuse into the agar at room temperature for 1 hour before incubation at $37{ }^{\circ} \mathrm{C}$ for 18 hours (bacteria) and $30{ }^{\circ} \mathrm{C}$ for 48 hours (fungi). The zones of inhibition of microbial growth were thereafter measured to the nearest millimeter.

Determination of the effects of varying temperature on the antimicrobial activity of Ficus sycomorus leaf extract

The extract $(2.5 \mathrm{~g})$ was dissolved in $10 \mathrm{mls}$ of sterile distilled water. This gave a concentration of $250 \mathrm{mg} / \mathrm{ml}$. The set up was maintained at different temperatures $\left(37^{\circ} \mathrm{C}\right.$, $45^{\circ} \mathrm{C}, 70{ }^{\circ} \mathrm{C}$ and $100{ }^{\circ} \mathrm{C}$ ) in the water bath for thirty (30) minutes. Standard cultures were prepared as described earlier and used as described above. The zones of inhibition of microbial growth were thereafter measured to the nearest millimeter.

Determination of the effect of storage duration on the antimicrobial activity of the Ficus sycomorus and Ficus platyphylla

Ten (10) milliliters of $250 \mathrm{mg} / \mathrm{ml}$ of the dried ethanolic extracts stored at room temperature were prepared at 3 months intervals and assessed for antimicrobial activity using the agar well diffusion method as described above in the $\mathrm{pH}$ study. The zones of inhibition of microbial growth were thereafter measured the nearest millimeter and recorded.

\section{Determination of Minimum Inhibitory Concentration (MIC) \\ Graded concentration of the ethanolic} extracts $5 \mathrm{ml}$ each were mixed with melted $\left(45{ }^{\circ} \mathrm{C}\right) 5 \mathrm{ml}$ of double strength MuellerHilton agar and poured aseptically into sterile plates. The plates were allowed to set. Sterile paper discs in duplicates were aseptically placed equidistantly on the set agar. Thereafter, $10 \mu \mathrm{l}$ of the standardized bacterial cultures were inoculated on the sterile paper discs aseptically. The plates were allowed to stand for 1 hour and then incubated at $37{ }^{\circ} \mathrm{C}$ for 18 hours. Ciprofloxacin was used as standard antibiotics.

The same procedure was carried out for fungal culture using Sabouraud Dextrose Agar and incubated at $30{ }^{\circ} \mathrm{C}$ for 48 hours. Terbinafine $\mathrm{HCl}$ was used as the standard antimicrobial agent..

\section{Statistical analysis}

Results were expressed as mean \pm standard deviation. The data was analysed using Student's t-test. $\mathrm{P}<0.05$ was considered significant and $\mathrm{P}>0.05$ not significant.

\section{RESULTS}

The results of phytochemical analysis of the extracts of the plants revealed the presence of steroids, alkaloids, flavonoids, anthraquinones, tannins, saponins and reducing sugars (Table 1 ).

The effect of temperature on the plant extract showed that at various temperatures of $37{ }^{\circ} \mathrm{C}, \quad 45{ }^{\circ} \mathrm{C}, \quad 70{ }^{\circ} \mathrm{C}$ and $100{ }^{\circ} \mathrm{C}$, the antimicrobial activity remained relatively unaffected (Table 2). The antimicrobial activity of the extract maintained at $\mathrm{pH} 7$ and 9 is almost the same with that of the extract without $\mathrm{pH}$ buffer (Table 3). The stored extracts had almost the same effect on the test organisms as the fresh extracts. Thus, there were no significant changes in the antimicrobial activity of the extracts of the plants against the test organisms at $\mathrm{P}>0.05$ throughout the nine months period of investigation (Tables $4-7$ ).

The MIC values of the test extracts were higher than those of the standard antibiotics (Table 8). 
Table1: Phytochemical constituents of Ficus sycomorus and Ficus platyphylla leaves and stem barks.

\begin{tabular}{lcccc}
\hline \multirow{2}{*}{ Chemical constituents } & \multicolumn{2}{c}{ F. sycomorus } & \multicolumn{2}{c}{ F.platyphylla } \\
\cline { 2 - 5 } & Leaves & Stem barks & Leaves & $\begin{array}{r}\text { Stem } \\
\text { barks }\end{array}$ \\
\cline { 2 - 5 } & & & - & - \\
\hline Steroids/Terpenes & + & + & - & + \\
Alkaloids & + & + & + & + \\
Flavonoids & + & + & - & + \\
Anthraquinones & - & + & - & + \\
Tannins & + & + & - & - \\
Saponins & + & + & - & \\
Carbohydrates/sugars & + & + & &
\end{tabular}

Table 2: Effect of temperature on the antimicrobial activity of Ficus sycomorus leaf extract (250 $\mathrm{mg} / \mathrm{ml}$ ) test organisms.

\begin{tabular}{|c|c|c|c|}
\hline \multirow[t]{2}{*}{ Temperature $\left({ }^{\circ} \mathrm{C}\right)$} & \multicolumn{3}{|c|}{ Zones of inhibition (mm) } \\
\hline & CRSA & CRST & T. mentagrophytes \\
\hline $100(\mathrm{E})$ & $16.5 \pm 0.5$ & $12.5 \pm 1.1$ & NA \\
\hline $70(\mathrm{E})$ & $15.5 \pm 0.5$ & $12.5 \pm 0.5$ & NA \\
\hline $45(\mathrm{E})$ & $16.0 \pm 0.0$ & $12.5 \pm 0.5$ & NA \\
\hline $45(W)$ & NA & NA & NA \\
\hline $37(W)$ & NA & NA & NA \\
\hline
\end{tabular}

Table 3: Effect of varying $\mathrm{pH}$ values on the antimicrobial activity of Ficus sycomorus leaf extract $(250 \mathrm{mg} / \mathrm{ml})$ against test organisms

\begin{tabular}{|c|c|c|c|}
\hline \multirow[b]{2}{*}{ pH } & \multicolumn{3}{|c|}{ Zones of inhibition (mm) } \\
\hline & CRSA & CRST & T. mentagrophytes \\
\hline$* 6.7(\mathrm{E})$ & $16.0 \pm 0.0$ & $11.0 \pm 0.0$ & NA \\
\hline $4(\mathrm{E})$ & $17.0 \pm 0.0$ & $10.5 \pm 0.5$ & NA \\
\hline $7(\mathrm{E})$ & $16.5 \pm 0.5$ & $11.0 \pm 1.0$ & NA \\
\hline $9(\mathrm{E})$ & $16.5 \pm 0.5$ & $11.0 \pm 0.0$ & NA \\
\hline $4(\mathrm{~B})$ & NA & NA & NA \\
\hline $7(\mathrm{~B})$ & NA & NA & NA \\
\hline $9(\mathrm{~B})$ & NA & NA & NA \\
\hline
\end{tabular}

Key: CRSA = Ciprofloxacin-Resistant Staphylococcus aureus, CRST = Ciprofloxacin-Resistant Salmonella typhi, * original $\mathrm{pH}$ of extract, $\mathrm{E}=$ Extracts, $\mathrm{B}=$ Buffer alone, NA = No activity, The results are expressed as mean \pm standard deviation, No significant changes in the antimicrobial activities of the extracts at $\mathrm{P}>0.05$ at the different $\mathrm{pH}$. Diameter of well $=8 \mathrm{~mm}$. 
Table 4: Effect of storage on antimicrobial activity of Ficus sycomorus leaf extracts $(250 \mathrm{mg} / \mathrm{ml})$ against test organisms.

\begin{tabular}{lccc}
\hline & \multicolumn{3}{c}{ Zones of inhibition $(\mathbf{m m})$} \\
\cline { 2 - 4 } Storage duration & CRSA & CRST & T. mentagrophytes \\
\hline Fresh Extract & $16.0 \pm 0.0$ & $11.0 \pm 0.0$ & NA \\
1 month & $16.0 \pm 0.0$ & $11.0 \pm 0.0$ & NA \\
3 months & $16.0 \pm 0.0$ & $11.0 \pm 0.0$ & NA \\
6 months & $16.0 \pm 0.0$ & $11.0 \pm 0.0$ & NA \\
9 months & $16.0 \pm 0.0$ & $11.0 \pm 0.0$ & NA
\end{tabular}

Key: CRSA = Ciprofloxacin-Resistant Staphylococcus aureus, CRST = Ciprofloxacin-Resistant Salmonella typhi, NA = No activity, The results are expressed as mean \pm standard deviation, No significant changes in the antimicrobial activities of the extracts at $\mathrm{P}>0.05$ during the nine months duration. Diameter of well $=8 \mathrm{~mm}$.

Table 5: Effect of storage on antimicrobial activity of Ficus sycomorus stem bark extracts (250 $\mathrm{mg} / \mathrm{ml}$ ) against test organisms.

\begin{tabular}{lllc}
\hline & \multicolumn{3}{c}{ Zones of inhibition $(\mathbf{m m})$} \\
\cline { 2 - 4 } Storage duration & CRSA & CRST & T. mentagrophytes \\
\hline Fresh extract & $16.5 \pm 0.5$ & $18.0 \pm 1.0$ & NA \\
1 month & $16.5 \pm 0.5$ & $18.0 \pm 1.0$ & NA \\
3 months & $16.5 \pm 0.5$ & $18.0 \pm 1.0$ & NA \\
6 months & $16.0 \pm 0.0$ & $18.0 \pm 0.0$ & NA \\
9 months & $16.0 \pm 0.0$ & $18.5 \pm 0.5$ & NA
\end{tabular}

Key: CRSA = Ciprofloxacin-Resistant Staphylococcus aureus, CRST = Ciprofloxacin-Resistant Salmonella typhi, NA = No activity, The results are expressed as mean \pm standard deviation, No significant changes in the antimicrobial activities of the extracts at $\mathrm{P}>0.05$ during the nine months duration. Diameter of well $=8 \mathrm{~mm}$.

Table 6: Effect of storage on antimicrobial activity of Ficus platyphylla leaf extracts ( $250 \mathrm{mg} / \mathrm{ml})$ against test organisms.

\begin{tabular}{llcc}
\hline \multirow{2}{*}{ Storage duration } & CRSA & Cones of inhibition $(\mathrm{mm})$ \\
\cline { 2 - 4 } Fresh extract & $20.0 \pm 0.5$ & $25.5 \pm 0.5$ & T. mentagrophytes \\
1 month & $20.5 \pm 0.5$ & $25.0 \pm 0.0$ & NA \\
3 months & $20.5 \pm 0.5$ & $25.5 \pm 0.5$ & NA \\
6 months & $21.0 \pm 0.0$ & $24.5 \pm 0.5$ & NA \\
9 months & $20.5 \pm 0.5$ & $25.0 \pm 0.0$ & NA
\end{tabular}

Key: CRSA = Ciprofloxacin-Resistant Staphylococcus aureus, CRST = Ciprofloxacin-Resistant Salmonella typhi, NA = No activity, The results are expressed as mean \pm standard deviation, No significant changes in the antimicrobial activities of the extracts at $\mathrm{P}>0.05$ during the nine months duration. Diameter of well $=8 \mathrm{~mm}$.

Table 7: Effect of storage on antimicrobial activity of Ficus platyphylla stem bark extracts (250 $\mathrm{mg} / \mathrm{ml}$ ) against test organisms.

\begin{tabular}{lccc}
\hline & \multicolumn{3}{c}{ Zones of inhibition (mm) } \\
\cline { 2 - 4 } Storage duration & CRSA & CRST & T. mentagrophytes \\
\hline Fresh extract & $18.0 \pm 0.5$ & $21.0 \pm 0.0$ & NA \\
1 month & $17.5 \pm 0.5$ & $20.0 \pm 0.0$ & NA \\
3 months & $17.5 \pm 0.5$ & $20.0 \pm 1.0$ & NA \\
6 months & $17.5 \pm 0.5$ & $20.5 \pm 0.5$ & NA \\
9 months & $16.5 \pm 0.5$ & $20.0 \pm 0.0$ & NA \\
\hline Key: CRSA = Ciprofloxacin-Resistant Staphylococcus aureus, CRST $=$ Ciprofloxacin-Resistant Salmonella typhi, NA $=$ No \\
activity, The results are expressed as mean \pm standard deviation, No significant changes in the antimicrobial activities of the \\
extracts at P $>0.05$ during the nine months duration. Diameter of well $=8$ mm.
\end{tabular}


Table 8: Minimum Inhibitory Concentration (MIC) of the test plants leaves extracts and standard antibiotics against the test organisms.

\begin{tabular}{lcccc}
\hline & \multicolumn{4}{c}{ MIC $(\boldsymbol{\mu g} / \mathbf{m l})$} \\
\cline { 2 - 4 } Test organism & $\boldsymbol{F}$. sycomorous & $\boldsymbol{F}$. platyphylla & Ciprofloxacin & Terbinafine HCl \\
\hline CRSA & $3.13 \times 10^{4}$ & $7.8 \times 10^{3}$ & $7.5 \times 10^{0}$ & ND \\
CRST & $1.56 \times 10^{4}$ & $1.95 \times 10^{3}$ & $1.0 \times 10^{1}$ & ND \\
TM & $5.00 \times 10^{4}$ & $1.00 \times 10^{5}$ & ND & $1.28 \times 10^{2}$ \\
\hline Key: CRSA = Ciprofloxacin-Resistant Staphylococcus aureus; CRST = Ciprofloxacin-Resistant Salmonella typhi; \\
TM = Trichophyton mentagrophytes. The peak plasma concentration of ciprofloxacin is $2.5 \mu \mathrm{g} / \mathrm{ml}$ and the peak plasma \\
concentration of terbinafine HCl is $0.97 \mu \mathrm{g} / \mathrm{ml}$.
\end{tabular}

\section{DISCUSSION}

Phytochemical investigation of ethanolic extracts of leaves and stem barks of Ficus sycomorus and Ficus platyphylla obtained in Zaria, Nigeria revealed the presence of chemical constituents, such as saponins, alkaloids, flavonoids, anthraquinones, tannins, steroids and reducing sugars. The presence of these constituents has been reported in Ficus sycomorus stem bark in Sokoto and Maiduguri, Nigeria (Hassan, 2005; Sandabe et al., 2006). Similarly, the absence of anthraquinone in Ficus sycomorus leaf and the presence of alkaloids and flavonoids in the stem bark of Ficus platyphylla have also been documented in Jos, Zaria and Abuja, Nigeria (Kubmarawa et al., 2007; Ahmadu et al., 2007; Amos et al., 2001). These chemical constituents are secondary metabolites of plant that have been reported to serve as defense mechanisms against predation by many microorganisms, insects and herbivores (Karlovsky, 2008). The presence of these secondary metabolites may therefore explain the demonstration of antimicrobial activity observed from these extracts.

The presence of tannins in the Ficus sycomorus plants extracts may account for its effectiveness in wound healing. According to Sandabe et al. (2006), the extract contains a high amount of gallic tannins. Tannins precipitate proteins covering the surface of the cell or tissue, which acts as a barrier between tissue and irritants, and the underlying tissue is therefore soothed and protected from further damage, so that healing can take place (Shivananda et al., 2007).

The present study showed that at various temperature and $\mathrm{pH}$ ranges examined, the antimicrobial activities of the extracts remained relatively unaffected. This result suggests that the antimicrobial active chemical constituents of these plants extracts are heat stable. This finding also indicates that the plant extracts could still be effective after boiling. Doughari (2007) also reported that at various temperature ranges, the antibacterial activities of ethanol extracts of Balanites aegiptica and Moringa oleifera remained relatively unaffected but reduced when the $\mathrm{pH}$ was adjusted from acidic towards alkalinity (pH $8-10)$. These results are comparable to those of Mahfuzul et al. (2007) who demonstrated that $\mathrm{pH}$ and temperature have no significant effect on the antimicrobial activities of Guava and Neem extracts, against Staphylococcus aureus and L. monocytogenes.

The local application of most of the plants used by the herbalist involves the addition of high doses of potash (a strong basic salt) and lime, which is acidic (Okeke, 2008). The stability of these extracts in the investigated $\mathrm{pH}$ may explain why the plant concoction remains effective even when boiled with acid and alkali. Acid stability is an important property of drugs, because it means that the plant components can be formulated to be taken orally and will not be inactivated under the acidic conditions of the stomach and the gastrointestinal tract (El-Mahmood, 2009).

These plants extracts were also found to retain their antimicrobial activity after nine months storage duration. This is an indication that these plants extracts have stable antimicrobial activities over a period of time.

The MIC values of the crude ethanolic extracts of the test plants were observed to be significant compared to the test standard refined antimicrobial agents. These observed activities could be enhanced when the active components of the plants are isolated and examined. 
These findings will be of immense advantage in limiting the emergence of antibiotic-resistant pathogens that are so prevalent worldwide.

\section{Conclusion}

The ethanolic extracts of $F$. sycomorus and $F$. platyphylla leaves and stem bark contain chemical constituents which showed marked antimicrobial activities. The antimicrobial activity of the ethanolic extract of Ficus sycomorus leaf was found to be stable at varying temperatures up to $100{ }^{\circ} \mathrm{C}$ and also at different $\mathrm{pH}$ values (acidic, neutral and basic). Storage duration of nine months did not affect the antimicrobial activity of ethanolic extracts of $F$. sycomorus and $F$. platyphylla leaves and stem bark. These findings authenticate the claims of these plants in traditional medicine

\section{REFERENCES}

Ahmadu AA, Zezi AU, Yaro AH. 2007. Antidiarrhoeal activity of the leaf extracts of Daniella oliveri Hutch and Dalz (Fabaceae) and Ficus sycomorus Miq. (Moraceae). Afr. J. Trad. CAM., 4(4): $524-528$.

Amos S, Chindo B, Edmond I, Akah P, Wambebe C, Gamaniel K. 2002. Antiinflammatory and anti-nociceptive effects of Ficus platyphylla extracts in mice and rat. J. Evolutionary Biol., 18(15): 1234 - 1244 .

Amos S, Binda L, Chindo B, Akah P, Abdurahman M, Danmallam HU, Wambebe C, Gamaniel K. 2001. Evaluation of methanolic extract of Ficus platyphylla on gastrointestinal activity. Indian J. Exp. Biol., 39(1): 63 - 67.

Brain KR, Turner TD. 1975. Extraction Procedures in Practical Evaluation of Phyto-pharmaceuticals. Weight Scentechnical: Bristol, UK; 98.

Doughari JH. 2006. Antimicrobial activity of Tamarindus indica Linn. Trop. J. Pharm. Res., 5(2): $597-603$.

Doughari JH, Pukuma MS, De N. 2007. Antibacterial effects of Balanties aegyptiaca L. Del. and Moringa Oleifera Lam. on Salmonella typhi. Afr. J. Biotechnol., 6(19): $2212-2215$.

Dumitinu S. 2005. Polysaccharides: Structural Diversity and Functional
Versatility. CRC Press Amazon Company; 483.

Ehinmidu JO. 2005. Effect of light and heat on novel yam anti-rot preservatives. $J$. Trop. Biosci., 5(2): $8-11$.

El-Mahmood AM. 2009. Antibacterial activity of crude extracts of Euphorbia hirta against some bacteria associated with enteric infections. J. Med. Plants Res., 3(7): 498-505.

Hassan SW. 2005. Antimicrobial screening, phytochemical analysis and toxicological studies on some medicinal plants. Ph.D. Thesis. Usman Danfodio University, Sokoto, Nigeria. p. 82.

Hassan SW, Umar RA, Lawal M, Bilbis LS, Muhammad BY. 2006. Evaluation of antifungal activity of Ficus sycomorus L. (Moraceae). Biol. Eviron. Sci. J. Tropics. 3: $18-25$.

Karlovsky P. 2008. Secondary Metabolites in Soil Ecology. Springer Amazon Company; 244 - 245.

Kubmarawa D, Ajoku GA, Enwerem NM, Okorie DA. 2007. Preliminary phytochemical and antimicrobial screening of 50 medicinal plants from Nigeria. Afri. J. Biotechnol., 6(14): 16901696.

Kubmarawa D, Khan ME, Punah AM, Hassan M. 2009. Phytochemical and antimicrobial screening of Ficus platyphylla against human/animal pathogens. Pacific J. Sci. Technol., 10(1): $382-386$.

Mahfuzul Hoque MD, Bari ML, Inatsu Y, Vijay KJ, Kawamoto S. 2007. Antibacterial activity of guava (Psiduim guajava $\mathrm{L}$ ) and neem (Azadirachta indica A. Juss) extracts against food borne pathogens and spoilage bacteria. Food Borne Pathogens and Disease, 4(4): 481488.

Okeke CE. 2008. In vitro antimicrobial activities of the ethanolic extracts of Ficus sycomorus Linn. and Ficus platyphylla Del. (Moraceae). An M.Sc thesis of Ahmadu Bello University, Zaria, Nigeria, p.103.

Oyi AR, Onaolapo JA, Haruna AK, Morah CO. 2007. Antimicrobial screening and stability studies of the crude extract of Jatropha curcas linn. latex. 
(Euphobiaceae). Nig. J. Pharm. Sci. 6(2):14-20.

Pravin CT. 2006. Medicinal Plants: Traditional Knowledge. I.K. International Pvt. Ltd.: New Delhi; 216.

Sandabe UK, Onyelili PA, Chibuzo GA. 2006. Phytochemical screening and effects of aqueous extract of Ficus sycomorus L. (Moraceae) stem bark on muscular activity in laboratory animals. $J$. Ethnopharmacol., 104: 283-285.

Sandabe UK, Onyelili PA, Chibuzo GA. 2003. Sedative and anticonvulsant effects of aqueous extract of Ficus sycomorus L. (Moraceae) stem bark in rats. VETERINARSKI ARHIV. 73(2): 103110.

Shivananda B, Sivachandra-Raju S, Chalapathi-Rao AN. (2007). Wound healing activity of Matricaria recutita L. extract. J. Wound Healing. 16(7): 298302.

Sofowora A. 1982. Medicinal Plants and Traditional Medicine in Africa. Spectrum Books Ltd: Lagos; 135 - 140, 168 - 171.

Sofowora A. 1993. Standardization of herbal medicine. In Medicinal Plants and Traditional Medicine in Africa. Spectrum Books Ltd: Lagos; 55 - 61 .
Trease GE, Evans WC. 1996. Pharmacognosy $\left(11^{\text {th }}\right.$ edn). Braillar Tiriden Company, Macmillan Publishers; 56 - 109.

Wakeel OK, Aziba PI, Ashorobi RB, Umukoro S, Aderibigbe AO, Awe EO. 2004. Neuropharmacological activities of Ficus platyphylla stem bark in mice. Afr. J. Biomed. Res., 7(2): 75-78.

Webster AA. 2008. Pharmaceutical product stability. In Pharmaceutical Manufacturing Handbook, Gad SC (ed). John Wiley and Sons Inc.; 687 - 700.

Willey JM, Sherwood LM, Woolverton CJ. 2008. Presscott, Harley and Klein's Microbiology ( $7^{\text {th }}$ edn). McGraw-Hill Companies, Inc.; 357- 383.

World Health Organization 2007. WHO good manufacturing practices. In Quality Assurance of Pharmaceuticals. A Compendium of Guidelines and Related Materials. Good Manufacturing Practices and Inspection, Volume 2, send updated edition. World Health Organisation: Geneva, Switzerland.

Zerega, NJC, Clement WL, Datwley SL, Weiblen GD. 2005. Biogroegraphy and divergence times in the mulberry family Moraceae. Molecular Phylogenetics Evol., 37(2): 402 - 416. 